\title{
Extraabdominal Desmoid Tumor Appearing Following Resection of Thoracolumbar Schwannoma
}

\author{
Torakolomber Schwannom Cerrabisi Sonrası Ortaya Çıkan \\ Ekstraabdominal Desmoid Tümör
}

\author{
Erkin SONMEZ ${ }^{1}$, Nur ALTINORS ${ }^{1}$, Salih GULSEN ${ }^{1}$, Ozlem OZEN ${ }^{2}$ \\ ${ }^{1}$ Baskent University, Faculty of Medicine, Department of Neurosurgery, Ankara, Turkey \\ ${ }^{2}$ Baskent University, Faculty of Medicine, Department of Pathology, Ankara, Turkey
}

Correspondence address: Erkin SONMEZ / E-mail: erkinso@gmail.com

\begin{abstract}
The authors report the case of an adult female patient who developed a thoracic paraspinous desmoid tumor (aggressive fibromatosis) located just cranially to the incision scar of the previous surgery for resection of a spinal schwannoma. To the best of the authors' knowledge, this is the first report of an extraabdominal desmoid tumor occurring after resection of a spinal schwannoma. Desmoid tumors develop from muscle connective tissue, fasciae and aponeuroses. They are known to occur in association with surgical scars or implants. Incidence of this tumor is low. The etiology is still uncertain. Although rare, this distinctive tumor should be kept in mind in the differential diagnosis of palpable masses and especially those occurring around the previous skin incisions.
\end{abstract}

KEYWORDS: Aggressive fibromatosis, Extraabdominal desmoid tumor, Spinal tumor, Schwannom

öz

Yazarlar torakolomber spinal schwannom cerrahisini takiben yara yerinin hemen kranialinde, torakal paraspinöz bölgede, ortaya çıkan ağrılı, palpabl şişlik ile başvuran erişkin bir bayan hastayı sunuyorlar. Patoloji sonucu ekstraabdominal desmoid tumor (agresif fibromatoz) ile uyumlu olarak raporlanan hasta mevcut literatür eşliğinde tartışılıyor. Yazarların yaptığı literatür taraması sonucunda bu olgu literatürde, spinal schwannom cerrahisini takiben ortaya çıkan ilk desmoid tümör olgusu olarak dikkat çekiyor. Desmoid tümörler genellikle kas bağ dokusu, fasya ve aponörozlardan köken alırlar. Literatürde insizyon skarları ve cerrahi protezlerle yakın ilişkileri gösterilmiştir. İnsidansı çok düşük olan bu tümörün etiyolojisi hala kesin olarak bilinmemektedir. Nadir olmalarına rağmen, eski insizyon skar çevrelerinde ortaya çıkan şişliklerin ayırıcı tanılarında akılda tutulmalıdırlar.

ANAHTAR SÖZCÜKLER: Agresif fibromatoz, Ekstraabdominal desmoid tümör, Spinal tümör, Scwannom

\section{INTRODUCTION}

Aggressive fibromatosis (desmoid tumor) that develops from muscle connective tissue, fascia and aponeuroses, was first described by McFarlane in 1832 . It accounts for $0.03 \%$ of all neoplasms $(2,4)$. Desmoid tumors rarely show malignant transformation. They do not metastasize but are very invasive locally.

\section{CASE REPORT}

A 55-year-old woman underwent evaluation at our clinic for a painful thoracic paraspinous mass located $3 \mathrm{~cm}$ above the scar of a previous skin incision. This mass had existed for nearly six months. She had a history of lumbar disc surgery four years ago. Three years after disc surgery, she underwent a T10-L1 laminectomy for the resection of a spinal schwannoma. She was discharged uneventfully. The patient's neurological examination was unremarkable. Lumbar and thoracolumbar verticomedian incision scars were noticed on the back. A firm, tender paraspinous mass measuring approximately $6 \times 4 \mathrm{~cm}$ was palpated just cranial to the upper skin incision. Magnetic resonance imaging (MRI) of the thoracic spine revealed a mass lesion originating from the right paravertebral muscles at the thoracic level. Any communication with the spinal canal or bone destruction was not evident (Figure 1A, B, C). She was operated upon. The tumor was very invasive to the surrounding muscle tissue. It was completely resected with wide margins due to lack of an obvious tumor cleavage. Histopathologic examination revealed an extraabdominal desmoid tumor (Figure 2A, B).

\section{DISCUSSION}

The exact pathogenesis of desmoid tumor is unknown, however, genetic abnormalities (Familial adenomatous polyposis and Gardner's syndrome), sex hormones and trauma, especially surgical trauma have been considered as causative factors (1-5). The majority of cases occur between puberty and 40 years. MRI is the imaging method of choice for both preoperative planning and post-treatment monitoring. 

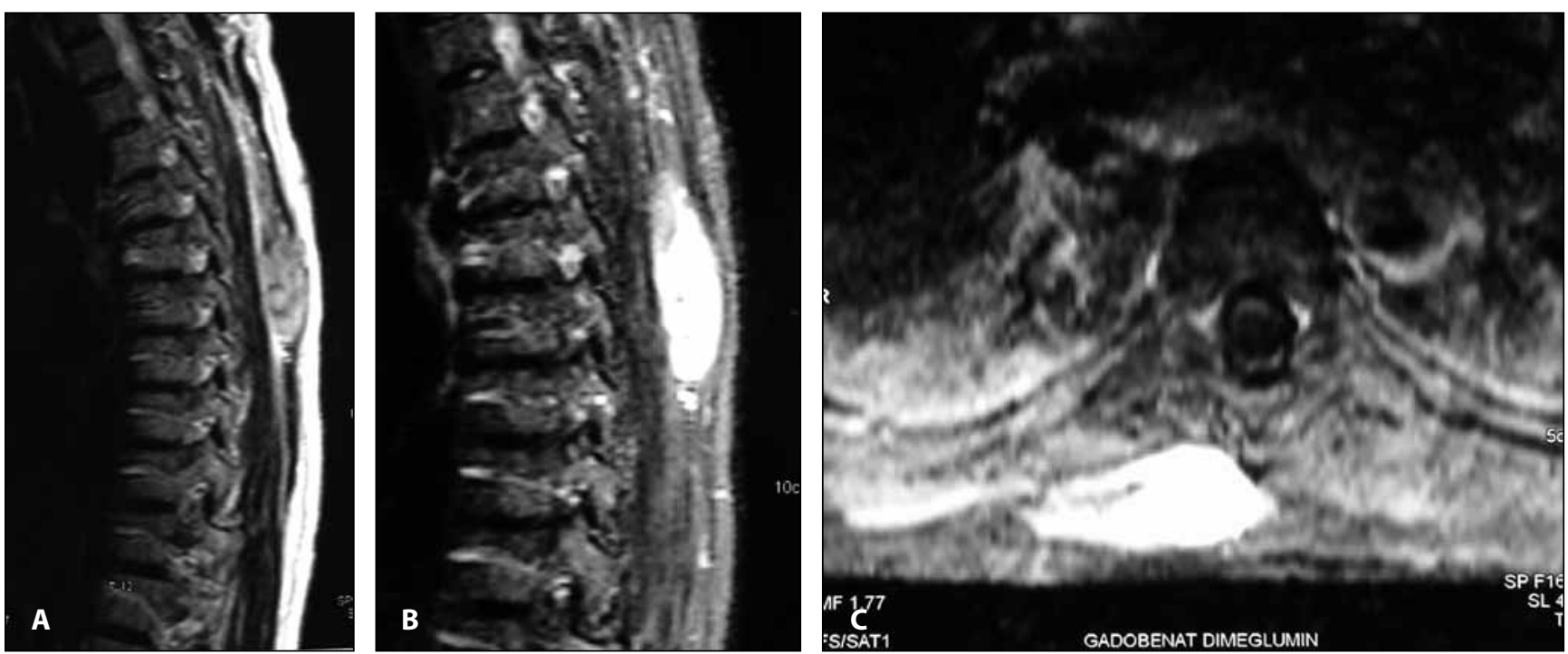

Figure 1: A-B) A high signal is present on T2-weighted and STIR images, respectively. C) The lesion enhances avidly after iv contrast administration.
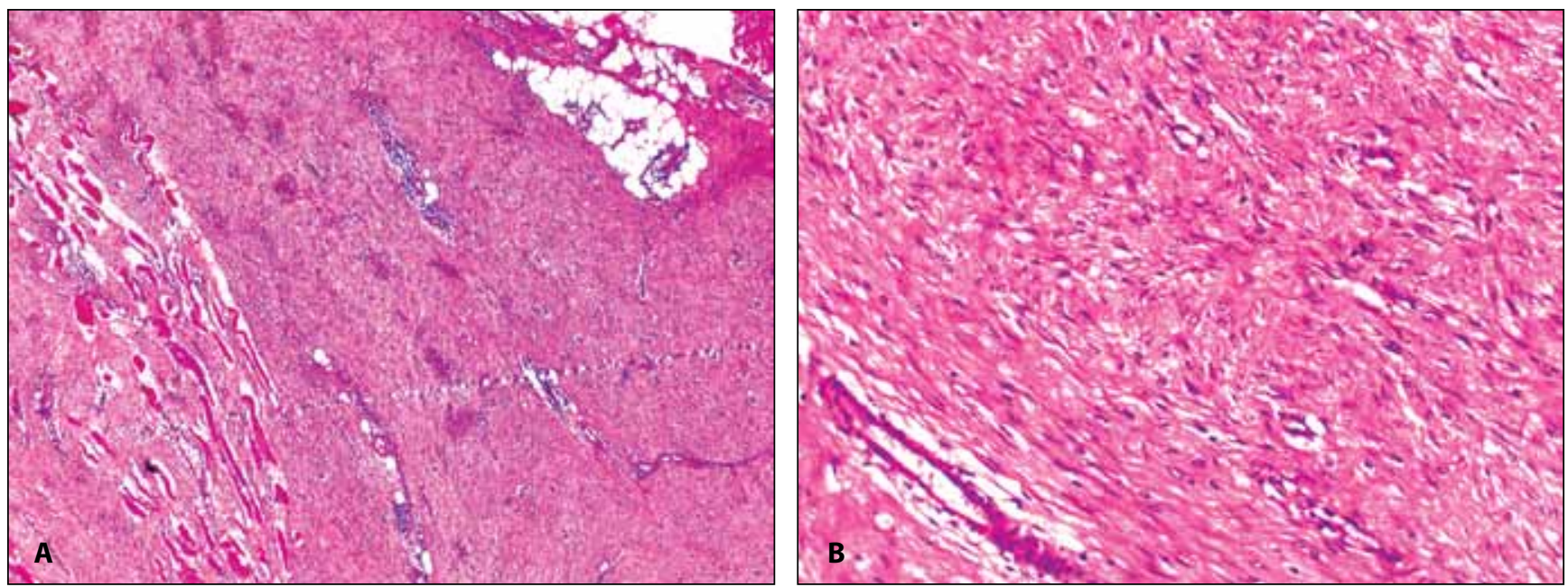

Figure 2: A) Extraabdominal fibromatosis. Note irregular infiltrative margins and entrapped skeletal muscle cells within the tumor mass ( $\mathrm{HE}$, original magnification $\mathrm{x} 40$ ). B) The tumor is composed of spindle and stellate cells with a vesicular nucleus (HE, original magnification 200x).

Unexplained etiology and the various locations make desmoid tumor treatment extremely difficult. At present there is no definite and effective method of treatment. Frequently, a wide surgical excision is made with a margin of clean tissues (1-2 cm), although sometimes this is impossible and remains the principle therapeutic maneuver $(2,3)$. However, a high recurrence rate after surgery has led to more conservative therapeutic management. Gronchi et al. reported that function-sparing surgery might be a reasonable choice without leaving macroscopic residual disease (1). Dalen et al concluded that desmoid tumors have probably been overtreated in the past. Many of them tend to regress spontaneously and might have a high capacity for self-limitation. Conservative therapy should be considered in symptom-free patients (1).
There are also many reports describing a good response of desmoid tumors to irradiation. Cytostatic agents, hormonal drugs, non-steroid anti-inflammatory drugs and anti-viral preparations are drugs that can be used in desmoid tumor treatment (2-5).

Our literature survey revealed that the presented case is the first desmoid tumor growing after resection of a spinal schwannoma. Although de novo development of the tumor is possible, we think that the tumor developed in response to previous spinal surgery.

\section{CONCLUSION}

In conclusion, a desmoid tumor should be considered in the differential diagnosis of any rapidly growing mass that arises 
around a previous surgically-treated site. Many treatment options are available and individualizing the management of the desmoid tumor would be the best policy.

\section{REFERENCES}

1. Dalen BPM, Geijer M, Kvist H, Bergh PM, Gunterberg BUP: Clinical and imaging observations of desmoid tumors left without treatment. Acta Orthopaedica 77(6):932-937, 2006

2. Ferenc T, Sygut J, Kopczynski J, Mayer M, Latos-Bielenska A, Dziki A, Kulig Andrzej: Aggressive Fibromatosis (Desmoid Tumors): Definition, occurrence, pathology, diagnostic problems, clinical behavior, genetic Background. Pol J Pathol 57(1):5-15, 2006
3. Gronchi A, Casali PG, Mariani L, Lo Vullo S, Colecchia M, Lozza L, Bertulli R, Fiore M, Olmi P, Santinami M, Rosai J: Quality of surgery and outcome in extra-abdominal aggressive fibromatosis: A series of patients surgically treated at a single institution. J Clin Oncol 21(7):1390-1397, 2003

4. Guzey FK, Emel E, Bas NS, Ozkan N, Turgut H, Sel B: Aggressive postoperative lumbar fibromatosis after the placement of instrumentation for treatment of spondylolisthesis. J Neurosurg Spine 4:338-341, 2006

5. Lynch JJ, Parvizi J, Scheithauer BW, Krauss WE: Development of postoperative fibromatosis after resection of an intraspinal menengioma. J Neurosurg (Spine 1) 90:121-124, 1999 